Web Site: https://jutq.utq.edu.iq/index.php/main

Email: journal@jutq.utq.edu.iq

\title{
Radon Exhalation Rate and Mean Annual Effective Dose from Radium concentration from Gharraf Canal and Its Some Branches in Thi Qar Governorate (Iraq) https://doi.org/10.32792/utq/utj/vol12/1/7
}

\section{Hayder Abdulwahid Hammood General Directorate of Education in Thi Qar, Thi Qar, Iraq h.a.hammood10@gmail.com}

\section{Abstract}

The radon exhalation rate in term of area was variable (10.4-52.1 $\left.\mathrm{mBq} \cdot \mathrm{m}^{-2} \cdot \mathrm{h}^{-1}\right)$ with the average value $\left(30.1 \mathrm{mBq} \cdot \mathrm{m}^{-2} \cdot \mathrm{h}^{-1}\right)$ while the radon exhalation rate in term of mass was variable $\left(1.09-5.45 \mathrm{mBq} \cdot \mathrm{kg}^{-1} \cdot \mathrm{h}^{-1}\right)$ with the average value $\left(3.15 \mathrm{mBq} \cdot \mathrm{kg}^{-1} \cdot \mathrm{h}^{-1}\right)$ and radium concentration is varied (0.144-0.722 Bq. $\left.\mathrm{kg}^{-1}\right)$ with the average value $\left(0.417 \mathrm{~Bq} \cdot \mathrm{kg}^{-1}\right)$. The annual effective dose of radium for three population groups was carried out, and lifetime risk assessment was about $10^{-4}$ when used this water as a drinking water. The results compared with safe recommended limit to radium concentration and the annual effective dose of radium in drinking water according to $\mathrm{WHO}$ and with other countries.

Keywords: Radon exhalation rate, radium, mean annual effective dose, Gharraf canal.

\section{معدل انبعاث الرادون والجرعة السنوية الفعالة الناتجة من تركيز الراديوم في قناة الغراف وبعض فروعها في محافظة ذي قار (العراق)}

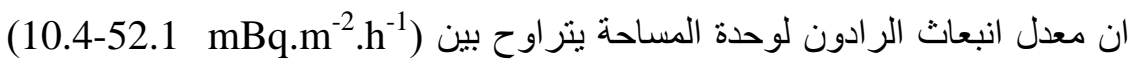

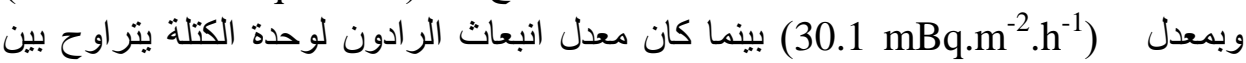
(1.09-5.45 mBq.kg-1 وبمعدل (3.15 mBq.

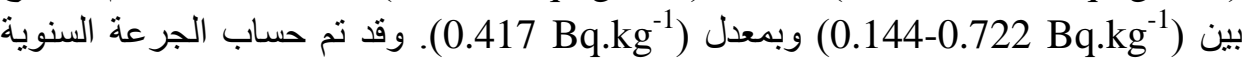
الفعالة للراديوم الثلاث مجموعات عمرية من السكان, وان تقدير المخاطر لمدى العمر كان بحدود 


\section{University of Thi-Qar Journal Vol.12 No.1 Mar 2017}

Web Site: https://jutq.utq.edu.iq/index.php/main

Email: journal@jutq.utq.edu.iq

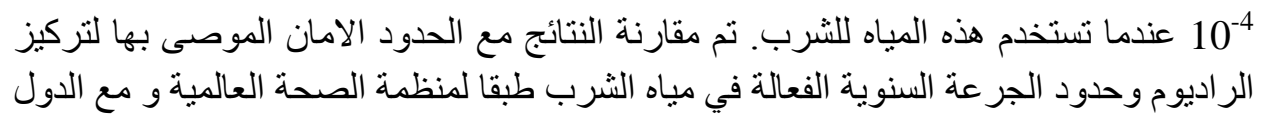

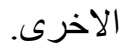

\section{Introduction}

Radium is element radioactive, it's the direct parent of radon radioactive gas, radium and radon come from uranium decay series [AlKhalifa, 2006, Barooah et al., 2013], The earth considers as source to many radioactive elements, where uranium, radium and radon are found in soil, air and water. These radioactive elements can enter the human body by inhalation and ingestion and might cause a health risk. Therefore, the monitoring of these radionuclides was increasing at any level [Singh et al., 2007].

Radium similar calcium when its inters the body is deposited in bone tissue and cause the bone cancer and other problems [Mahur et al, 2008]. While inhaling of radon released from water which uses in different purpose may cases lung cancer and ingesting of radon in drinking water may have stomach cancer [Kurnaz and Atıf Çetiner, 2016]. Where radon soluble in water, about 0.51 of radon may have soluble in 11 of water at $0^{\circ} \mathrm{c}$, therefore, the solubility of radon in water is height specially at reduction the temperature and concentration of other salts [Voronov, 2004]. So radium and its daughters in water are causing for a base part of the internal dose absorbed by population from the natural radioactive decay [Tabar and Yakut, 2014].

Gharraf canal is drilled from Tigris river by the Sumerian king (Antena) [Jabir, 2008]. The length of this canal in the land of Thi Qar governorate about $(141 \mathrm{~km})$ which is $(61.3 \%)$ of the total length of the canal, and also the total lengths of branches is $(732.5 \mathrm{~km})$ in Thi Qar governorate [Ahmed, 2007]. The population of this governorate about (1979561) according to CSO [CSO, 2014]. The water of Gharraf canal and its branches are irrigate $50.77 \%$ of the agricultural area in Thi Qar governorate [Jabir, 2008]. The water also is supplied to public in most 


\section{University of Thi-Qar Journal Vol.12 No.1 Mar 2017 \\ Web Site: https://jutq.utq.edu.iq/index.php/main \\ Email: journal@jutq.utq.edu.iq}

areas of Thi Qar and used as a source of drinking water in some areas, where there are people drinking water from Ghrraf river and branches immediately, some other drinking from supplied water to the public and the third group of people drinking the reverse osmosis (RO) water (RO water reduces the concentration of radiating elements in water [EPA, 2015]). Gharraf canal passage through three regions in Thi Qar governorate, Al-Rufai region (including The districts are Al-Fager, Qalat Sukar, Al-Rufai and Al-Naser), Al-Shatrah region (including The districts are Dwaya, Al-Shatrah and Gharraf) and Al-Nassiriah region (including The districts are Al-Nassiriah Said Dkile and Al-Islah). As shown in figure 1.

In this study solid state nuclear track detector SSNTDs LR-115 type II used to evaluate radon exhalation rates in terms of area and mass, and radium concentration in water of Gharraf canal and Its some branches in Thi Qar governorate of Iraq to have a database about the radiating elements concentration. Knowledge mean annual effective dose and assessment risk life from radium concentration when used this water as a drinking water. 


\section{University of Thi-Qar Journal Vol.12 No.1 Mar 2017}

Web Site: https://jutq.utq.edu.iq/index.php/main

Email: journal@jutq.utq.edu.iq

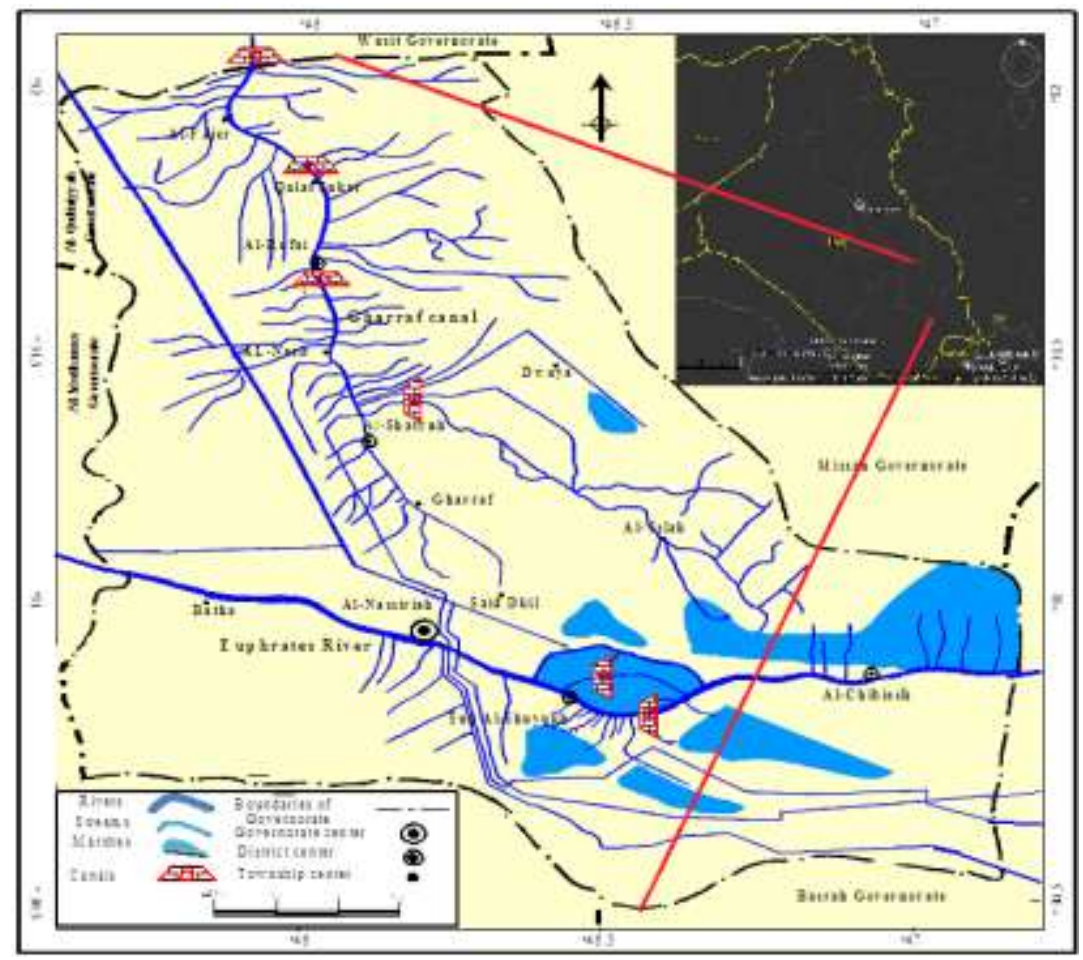

Figure 1. Surface water map in Thi Qar Governorate.

\section{Materials and Method}

31 samples of water were collected from Gharraf canal and Its some branches in different places in Thi Qar governorate. Every sample $12 \mathrm{~g}$ placed at the bottom of a closed cylindrical plastic container $(4 \mathrm{~cm}$ diameter) and LR-115 type II detector at the mouth, this arrangement shown in figure 2. After three months the detector extracted and chemically etched using a $(\mathrm{NaOH})$ solution of $\left(2.5 \mathrm{~N}\right.$ at $60 \pm 1{ }^{\circ} \mathrm{C}$ for $\left.2 \mathrm{~h}\right)$. The ordinary microscope uses to count alpha tracks in SSNTDs LR-115 type II detectors. 


\section{University of Thi-Qar Journal Vol.12 No.1 Mar 2017 \\ Web Site: https://jutq.utq.edu.iq/index.php/main \\ Email: journal@jutq.utq.edu.iq}

The radon exhalation rate in term of area $\mathrm{E}_{\mathrm{A}}$ and mass $\mathrm{E}_{\mathrm{M}}$ from water determined according to the following equations [Sonkawade et al., 2008]:

$$
\begin{aligned}
& E_{A}=C V \lambda / A\left[t+1 / \lambda\left(e^{-\lambda t}-1\right)\right] \\
& E_{M}=C V \lambda / M\left[t+1 / \lambda\left(e^{-\lambda t}-1\right)\right]
\end{aligned}
$$

Where $\mathrm{C}$ is the integrated radon exposure of the water sample $\left(\mathrm{Bq} \cdot \mathrm{m}^{-3} \cdot \mathrm{h}\right)$, $\mathrm{V}$ is the volume of air in the cylindrical plastic container $\left(\mathrm{m}^{3}\right), \lambda$ is the decay constant of radon $\left(\mathrm{h}^{-1}\right)$ which emanates from water samples, $\mathrm{A}$ is the surface area of the water sample $\left(\mathrm{m}^{2}\right), \mathrm{M}$ is the mass of the water sample $(\mathrm{kg})$ and $\mathrm{t}$ is the time of exposure $(\mathrm{h})$.

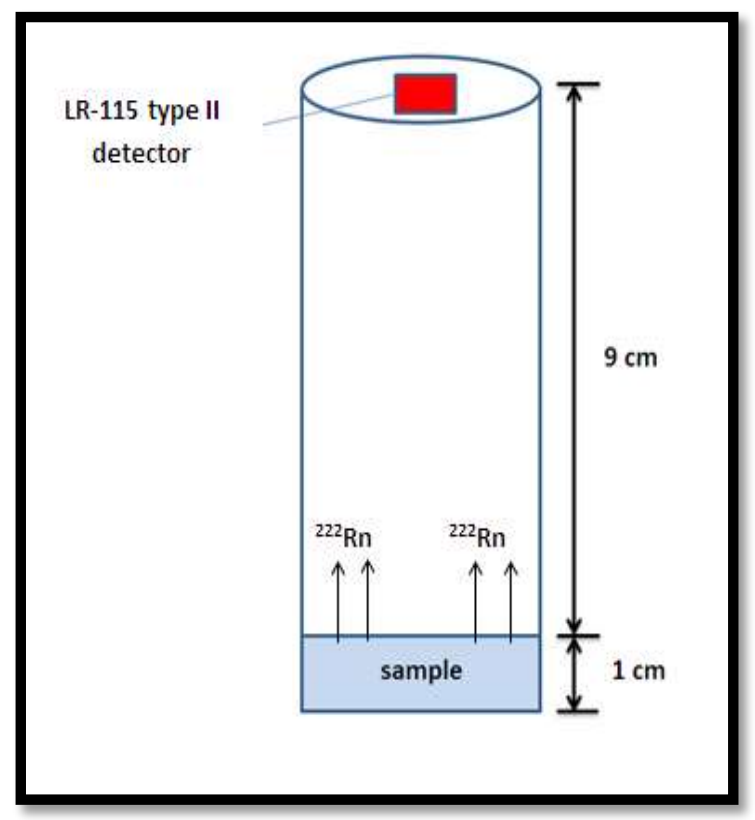

Figure 2. Arrangement of (SSNTDs LR-115 type II) films and a water sample in a closed cylindrical plastic container.

Radium concentration $\mathrm{C}_{\mathrm{Ra}}$ in water samples calculated using the equation (3) [Prasad et al., 2008]: 


\section{University of Thi-Qar Journal Vol.12 No.1 Mar 2017 \\ Web Site: https://jutq.utq.edu.iq/index.php/main \\ Email: journal@jutq.utq.edu.iq}

$C_{R a}=\frac{\rho h A}{K T_{e} M}$

Where $\rho$ is the track density due to radon $\left(\right.$ tracks. $\left.\mathrm{cm}^{-2}\right), \mathrm{h}$ is the distance between the detector and the top of the sample $(\mathrm{m})$ and $\mathrm{T}_{\mathrm{e}}$ is the effective time of exposure (d).

The calibration factor $\mathrm{K}$ given by the following equation [Somogyi et al., 1984]:

$$
K=\frac{1}{4} a \cos \theta_{c}\left(2-\frac{a_{1}}{a}-\frac{a}{a_{\circ}}\right) \quad \text { If }\left(\mathrm{a}_{1} \leq \mathrm{a} \leq \mathrm{a}_{0}\right)
$$

Where (a) is the radius of the cylindrical plastic container. $\theta_{c}$ is the critical angle $\left(40^{\circ}\right) \cdot a_{\mathrm{o}}=\mathrm{R}_{\mathrm{o}} \cos \theta_{\mathrm{c}}, a_{1}=\mathrm{R}_{1} \cos \theta_{\mathrm{c}}, \mathrm{R}_{\mathrm{o}}=\mathrm{R}-\mathrm{R}_{\min }, \mathrm{R}_{1}=\mathrm{R}-\mathrm{R}_{\max }$.

$\mathrm{R}$ is the alpha range of radon in air $(3.90 \mathrm{~cm}),\left(\mathrm{R}_{\max }=3.44 \mathrm{~cm}, \mathrm{R}_{\min }=0.80\right.$ $\mathrm{cm})$ [Misdaq et al., 1997]. The calibration factor is $\left(0.032\right.$ tracks.cm ${ }^{-}$ ${ }^{2}$.day $^{-1}$ per Bq. ${ }^{-3}$ ) which compared with [Klein et al., 1995, fahad, 2001].

\section{Results and Discussion}

Table 1 showed radon exhalation rate in terms of area and mass in water samples were collected from Gharraf canal and Its some branches in different places from Al-Rufai, Al-Shatrah and Al-Nassiriah regions in Thi Qar governorate.

While the annual effective dose of radium in drinking water $\mathrm{D}$ was calculated according to equation (5):

$$
\mathrm{D}=\mathrm{C}_{\mathrm{Ra}} \mathrm{U}_{\mathrm{a}} \mathrm{D}_{\mathrm{f}}
$$

Where $U_{a}$ is the annual intake of water were 150,350 and $500 \mathrm{~kg} . \mathrm{a}^{-1}$ for infants, children and adults respectively [ICRP, 1994], these division considered according to [UNSCEAR, 2000]. $\mathrm{D}_{\mathrm{f}}$ is the dose conversion 


\section{University of Thi-Qar Journal Vol.12 No.1 Mar 2017 \\ Web Site: https://jutq.utq.edu.iq/index.php/main \\ Email: journal@jutq.utq.edu.iq}

factor of the specific radionuclide are given for three population groups by [ICRP, 1996]. Radium concentration and the annual effective dose of radium in this water for infants, children and adults are obtained in table 2.

Table 1. Show radon exhalation rate in terms of area and mass from Gharraf canal and Its some branches of Thi Qar governorate.

\begin{tabular}{|c|c|c|c|c|c|}
\hline No. & The region & The district & $\begin{array}{l}\text { Name of The } \\
\text { canal or the } \\
\text { branch }\end{array}$ & $\begin{array}{l}E_{A} \\
\left(m B q \cdot m^{-2} \cdot h^{-1}\right)\end{array}$ & $\begin{array}{l}E_{M} \\
\left(m B q \cdot k^{-1} \cdot h^{-1}\right)\end{array}$ \\
\hline 1 & \multirow{12}{*}{ Al-Rufai } & \multirow[t]{3}{*}{ Al-Fager } & Gharraf(1) & 31.3 & 3.27 \\
\hline 2 & & & Almkhishi & 52.1 & 5.45 \\
\hline 3 & & & Alashtiraki & 52.1 & 5.45 \\
\hline 4 & & \multirow{3}{*}{ Qalat Sukar } & Husseiniya & 20.8 & 2.18 \\
\hline 5 & & & Almcefna & 46.9 & 4.91 \\
\hline 6 & & & Alhabibia & 10.4 & 1.09 \\
\hline 7 & & \multirow[t]{3}{*}{ Al-Rufai } & Alsablah alkabir & 20.6 & 2.16 \\
\hline 8 & & & Zaidiya & 30.9 & 3.23 \\
\hline 9 & & & Alchroah & 51.5 & 5.39 \\
\hline 10 & & \multirow[t]{3}{*}{ Al-Naser } & Al Hatam & 41.7 & 4.36 \\
\hline 11 & & & Alnaumiyah & 10.4 & 1.09 \\
\hline 12 & & & Gharraf(2) & 10.4 & 1.09 \\
\hline 13 & \multirow{12}{*}{ Al-Shatrah } & \multirow[t]{4}{*}{ Al-Shatrah } & Gharraf(3) & 31.6 & 3.31 \\
\hline 14 & & & Alimhadiyh & 31.6 & 3.31 \\
\hline 15 & & & Alkhoania & 38.7 & 4.05 \\
\hline 16 & & & Khirbit & 31.6 & 3.31 \\
\hline 17 & & \multirow[t]{4}{*}{ Dwaya } & Al Fahal & 31.6 & 3.31 \\
\hline 18 & & & Majidiyah & 21.1 & 2.21 \\
\hline 19 & & & Alchabshiy & 42.2 & 4.41 \\
\hline 20 & & & Maa Dwaya & 21.1 & 2.21 \\
\hline 21 & & \multirow[t]{4}{*}{ Gharraf } & Shatt Al-Shatra & 10.6 & 1.10 \\
\hline 22 & & & Alrezaqaih & 10.6 & 1.10 \\
\hline 23 & & & Abu Shabibah & 21.1 & 2.21 \\
\hline 24 & & & Bahisah & 10.6 & 1.10 \\
\hline 25 & \multirow{7}{*}{ Al-Nassiriah } & \multirow[t]{2}{*}{ Al-Nassiriah } & Khumessat & 23.2 & 2.43 \\
\hline 26 & & & Al Boudjemaa & 21.1 & 2.21 \\
\hline 27 & & \multirow[t]{2}{*}{ Said Dkile } & Al Brahim & 31.6 & 3.31 \\
\hline 28 & & & Al Toman & 50.1 & 5.24 \\
\hline 29 & & \multirow[t]{3}{*}{ Al-Islah } & Gddeer & 38.7 & 4.05 \\
\hline 30 & & & Snan & 47.5 & 4.97 \\
\hline 31 & & & Al Hsen & 38.7 & 4.05 \\
\hline
\end{tabular}




\section{University of Thi-Qar Journal Vol.12 No.1 Mar 2017}

Web Site: https://jutq.utq.edu.iq/index.php/main

Email: journal@jutq.utq.edu.iq

Table 2. Show radium concentration and the annual effective dose of radium for three population groups in drinking water from Gharraf canal and Its some

branches of Thi Qar governorate.

\begin{tabular}{|c|c|c|c|c|c|c|c|}
\hline \multirow[t]{2}{*}{ No. } & \multirow[t]{2}{*}{ The region } & \multirow[t]{2}{*}{ The district } & \multirow{2}{*}{$\begin{array}{l}\text { Name of The } \\
\text { canal or the } \\
\text { branch }\end{array}$} & \multirow[t]{2}{*}{$\begin{array}{l}C_{R a} \\
\left(B q . \mathrm{kg}^{-1}\right)\end{array}$} & \multicolumn{3}{|c|}{$\begin{array}{l}\text { The annual effective dose } \\
D\left(m S v \cdot a^{-1}\right)\end{array}$} \\
\hline & & & & & $\begin{array}{l}\text { For } \\
\text { infants }\end{array}$ & $\begin{array}{l}\text { For } \\
\text { children }\end{array}$ & $\begin{array}{l}\text { For } \\
\text { adults }\end{array}$ \\
\hline 1 & \multirow{12}{*}{ Al-Rufai } & \multirow[t]{3}{*}{ Al-Fager } & Gharraf(1) & 0.433 & 0.0624 & 0.1212 & 0.0606 \\
\hline 2 & & & Almkhishi & 0.722 & 0.1040 & 0.2022 & 0.1011 \\
\hline 3 & & & Alashtiraki & 0.722 & 0.1040 & 0.2022 & 0.1011 \\
\hline 4 & & \multirow[t]{3}{*}{ Qalat Sukar } & Husseiniya & 0.289 & 0.0416 & 0.0809 & 0.0405 \\
\hline 5 & & & Almcefna & 0.650 & 0.0936 & 0.1820 & 0.0910 \\
\hline 6 & & & Alhabibia & 0.144 & 0.0207 & 0.0403 & 0.0202 \\
\hline 7 & & \multirow[t]{3}{*}{ Al-Rufai } & $\begin{array}{l}\text { Alsablah } \\
\text { alkabir }\end{array}$ & 0.285 & 0.0410 & 0.0798 & 0.0399 \\
\hline 8 & & & Zaidiya & 0.428 & 0.0616 & 0.1198 & 0.0599 \\
\hline 9 & & & Alchroah & 0.714 & 0.1028 & 0.1999 & 0.1000 \\
\hline 10 & & \multirow[t]{3}{*}{ Al-Naser } & Al Hatam & 0.577 & 0.0831 & 0.1616 & 0.0808 \\
\hline 11 & & & Alnaumiyah & 0.144 & 0.0207 & 0.0403 & 0.0202 \\
\hline 12 & & & Gharraf(2) & 0.144 & 0.0207 & 0.0403 & 0.0202 \\
\hline 13 & \multirow{12}{*}{ Al-Shatrah } & \multirow[t]{4}{*}{ Al-Shatrah } & Gharraf(3) & 0.438 & 0.0631 & 0.1226 & 0.0613 \\
\hline 14 & & & Alimhadiyh & 0.438 & 0.0631 & 0.1226 & 0.0613 \\
\hline 15 & & & Alkhoania & 0.536 & 0.0772 & 0.1501 & 0.0750 \\
\hline 16 & & & Khirbit & 0.438 & 0.0631 & 0.1226 & 0.0613 \\
\hline 17 & & \multirow[t]{4}{*}{ Dwaya } & Al Fahal & 0.438 & 0.0631 & 0.1226 & 0.0613 \\
\hline 18 & & & Majidiyah & 0.292 & 0.0420 & 0.0818 & 0.0409 \\
\hline 19 & & & Alchabshiy & 0.584 & 0.0841 & 0.1635 & 0.0818 \\
\hline 20 & & & Maa Dwaya & 0.292 & 0.0420 & 0.0818 & 0.0409 \\
\hline 21 & & \multirow[t]{4}{*}{ Gharraf } & $\begin{array}{l}\text { Shatt } \\
\text { Al-Shatra }\end{array}$ & 0.146 & 0.0210 & 0.0409 & 0.0204 \\
\hline 22 & & & Alrezaqaih & 0.146 & 0.0210 & 0.0409 & 0.0204 \\
\hline 23 & & & Abu Shabibah & 0.292 & 0.0420 & 0.0818 & 0.0409 \\
\hline 24 & & & Bahisah & 0.146 & 0.0210 & 0.0409 & 0.0204 \\
\hline 25 & \multirow{7}{*}{ Al-Nassiriah } & \multirow[t]{2}{*}{ Al-Nassiriah } & Khumessat & 0.321 & 0.0462 & 0.0899 & 0.0449 \\
\hline 26 & & & $\begin{array}{l}\text { Al } \\
\text { Boudjemaa }\end{array}$ & 0.292 & 0.0420 & 0.0818 & 0.0409 \\
\hline 27 & & \multirow[t]{2}{*}{ Said Dkile } & Al Brahim & 0.438 & 0.0631 & 0.1226 & 0.0613 \\
\hline 28 & & & Al Toman & 0.694 & 0.0999 & 0.1943 & 0.0972 \\
\hline 29 & & \multirow[t]{3}{*}{ Al-Islah } & Gddeer & 0.536 & 0.0772 & 0.1501 & 0.0750 \\
\hline 30 & & & Snan & 0.657 & 0.0946 & 0.1840 & 0.0920 \\
\hline 31 & & & Al Hsen & 0.536 & 0.0772 & 0.1501 & 0.0750 \\
\hline
\end{tabular}

Maximum, minimum and average of radon exhalation rate in terms of area and mass, radium concentration and the annual effective dose of 


\section{University of Thi-Qar Journal Vol.12 No.1 Mar 2017}

Web Site: https://jutq.utq.edu.iq/index.php/main

Email: journal@jutq.utq.edu.iq

radium in drinking water for three population groups in every region and in total were shown in table 3 .

In total, the radon exhalation rate in term of area was variable $\left(10.4-52.1 \mathrm{mBq} \cdot \mathrm{m}^{-2} \cdot \mathrm{h}^{-1}\right)$ with the average value $\left(30.1 \mathrm{mBq} \cdot \mathrm{m}^{-2} \cdot \mathrm{h}^{-1}\right)$ while the radon exhalation rate in term of mass was variable $(1.09-5.45 \mathrm{mBq} \cdot \mathrm{kg}$ $\left.{ }^{1} \cdot \mathrm{h}^{-1}\right)$ with the average value $\left(3.15 \mathrm{mBq} \cdot \mathrm{kg}^{-1} \cdot \mathrm{h}^{-1}\right)$ and radium concentration is varied (0.144-0.722 Bq. $\left.\mathrm{kg}^{-1}\right)$ with the average value $\left(0.417 \mathrm{~Bq} \cdot \mathrm{kg}^{-1}\right)$, all data were included the safe limit recommended of radium concentration in drinking water $1 \mathrm{~Bq} \cdot \mathrm{l}^{-1}\left(1 \mathrm{~Bq} \cdot \mathrm{kg}^{-1}\right)$ according to WHO [WHO, 2004]. But they were bigger than the maximum allowed value of $\left(0.185 \mathrm{~Bq} \cdot \mathrm{kg}^{-1}\right)$ EPA [EPA, 1976] exception samples (6), (11) and (12) in Al-Rufai region, samples (21), (22) and (24) in Al-Shatrah region.

Table 3. Show maximum, minimum and average of radon exhalation rate in terms of area and mass, radium concentration and the annual effective dose of radium for three population groups in drinking water in every region and in total

\begin{tabular}{|c|c|c|c|c|c|c|c|}
\hline \multirow[t]{2}{*}{$\begin{array}{l}\text { The } \\
\text { region }\end{array}$} & & \multirow[t]{2}{*}{$\begin{array}{l}E_{A} \\
\left(m B q \cdot m^{-2} \cdot h^{-1}\right)\end{array}$} & \multirow[t]{2}{*}{$\begin{array}{l}E_{M} \\
\left(m B q \cdot g^{-1} \cdot h^{-1}\right)\end{array}$} & \multirow[t]{2}{*}{$\begin{array}{l}C_{R a} \\
\left(B q \cdot \mathrm{kg}^{-1}\right)\end{array}$} & \multicolumn{3}{|c|}{$\begin{array}{l}\text { The annual effective dose } \\
D\left(m S v \cdot a^{-1}\right)\end{array}$} \\
\hline & & & & & $\begin{array}{l}\text { For } \\
\text { infants }\end{array}$ & $\begin{array}{l}\text { For } \\
\text { children }\end{array}$ & $\begin{array}{l}\text { For } \\
\text { adults }\end{array}$ \\
\hline \multirow{3}{*}{ Al-Rufai } & Maximum & 52.1 & 5.45 & 0.722 & 0.1040 & 0.2022 & 0.1011 \\
\hline & Minimum & 10.4 & 1.09 & 0.144 & 0.0207 & 0.0403 & 0.0202 \\
\hline & Average & 31.6 & 3.31 & 0.438 & 0.0630 & 0.1225 & 0.0613 \\
\hline \multirow{3}{*}{$\begin{array}{l}\text { Al- } \\
\text { Shatrah }\end{array}$} & Maximum & 42.2 & 4.41 & 0.584 & 0.0841 & 0.1635 & 0.0818 \\
\hline & Minimum & 10.6 & 1.10 & 0.146 & 0.0210 & 0.0409 & 0.0204 \\
\hline & Average & 25.2 & 2.64 & 0.349 & 0.0502 & 0.0977 & 0.0488 \\
\hline \multirow{3}{*}{$\begin{array}{l}\text { Al- } \\
\text { Nassiriah }\end{array}$} & Maximum & 50.1 & 5.24 & 0.694 & 0.0999 & 0.1943 & 0.0972 \\
\hline & Minimum & 21.1 & 2.21 & 0.292 & 0.0420 & 0.0818 & 0.0409 \\
\hline & Average & 35.8 & 3.75 & 0.496 & 0.0715 & 0.1390 & 0.0695 \\
\hline \multirow{3}{*}{ Total } & Maximum & 52.1 & 5.45 & 0.722 & 0.1040 & 0.2022 & 0.1011 \\
\hline & Minimum & 10.4 & 1.09 & 0.144 & 0.0207 & 0.0403 & 0.0202 \\
\hline & Average & 30.1 & 3.15 & 0.417 & 0.0600 & 0.1166 & 0.0583 \\
\hline
\end{tabular}

The annual effective dose of radium in drinking water for three population groups carried out, for infants were between (0.0207-0.1040 $\left.\mathrm{mSv} \cdot \mathrm{a}^{-1}\right)$ with the average value $\left(0.0600 \mathrm{mSv} \cdot \mathrm{a}^{-1}\right)$, while being between (0.0403-0.2022 $\mathrm{mSv}^{-1} \mathrm{a}^{-1}$ with the average value $\left(0.1166 \mathrm{mSv} \cdot \mathrm{a}^{-1}\right)$ for children, and for adults were between $\left(0.0202-0.1011 \mathrm{mSv}^{-1} \mathrm{a}^{-1}\right)$ with the 


\section{University of Thi-Qar Journal Vol.12 No.1 Mar 2017 \\ Web Site: https://jutq.utq.edu.iq/index.php/main \\ Email: journal@jutq.utq.edu.iq}

average value $\left(0.0583 \mathrm{mSv}^{-1} \mathrm{a}^{-1}\right)$. Some values of the annual effective dose of radium in drinking water exceed recommended limits suggested by WHO of (0.1 mSv. $\left.{ }^{-1}\right)$ [WHO, 2004], apparently, in samples (2), (3) and (9) in Al-Rufai region for three population groups. And a less proportion of samples (1), (5), (8) and (10) in Al-Rufai region, samples (13), (14), (15), (16), (17) and (19) in Al-Shatrah region and samples (27), (28), (29), (30) and (31) in Al-Nassiriah region for children only, these results obtained in table 2. Point out, the average value of the annual effective dose of radium in drinking water for children in Al-Rufai region $(0.1225$ $\left.\mathrm{mSv} \cdot \mathrm{a}^{-1}\right)$, Al-Nassiriah region $\left(0.1390 \mathrm{mSv} \cdot \mathrm{a}^{-1}\right)$ and total $\left(0.1166 \mathrm{mSv} \cdot \mathrm{a}^{-1}\right)$ have also exceeded the value of $\left(0.1 \mathrm{mSv} \cdot \mathrm{a}^{-1}\right)$, these details in table 3 . All the results of the annual effective dose of radium in drinking water were below the Jordanian level of $\left(0.5 \mathrm{mSv}^{-1} \mathrm{a}^{-1}\right)$ [Al-Amir et al., 2012].

To evaluate lifetime risk assessment, $7.3 \times 10^{-2} \mathrm{~Sv}^{-1}$ is the normal probability coefficient was recommended by ICRP [ICRP, 1991], 1kg per day a consumption rate was assumed and the dose coefficient is 280 $\mathrm{nSv} \cdot \mathrm{Bq}^{-1}$, to the age of 70 years, lifetime risk assessment obtained in table 4.

Table 4. Estimated lifetime risk of radium in drinking water of the Gharraf canal in Thi Qar governorate.

\begin{tabular}{|l|l|l|}
\hline The region & $C_{R a}\left(\mathrm{~Bq}^{\mathrm{kg}} \mathrm{g}^{-1}\right)$ & Lifetime risk \\
\hline Al-Rufai & 0.438 & $2.3 \times 10^{-4}$ \\
\hline Al-Shatrah & 0.349 & $1.8 \times 10^{-4}$ \\
\hline Al-Nassiriah & 0.496 & $2.6 \times 10^{-4}$ \\
\hline Total & 0.417 & $2.2 \times 10^{-4}$ \\
\hline
\end{tabular}

Maximum of the lifetime risk of radium was $\left(2.6 \times 10^{-4}\right)$ in Al-Nassiriah region, while minimum of the lifetime risk of radium was $\left(1.8 \times 10^{-4}\right)$ in Al-Shatrah region, and the average of the lifetime risk of radium risk of $\left(2.2 \times 10^{-4}\right)$.

Also the results of radium concentration compared with other countries in table 5. Observably, the range radium concentration of Gharraf canal (0.144-0.722 Bq. $\left.\mathrm{kg}^{-1}\right)$ was greater than the results of United State, China, Poland and Romania, while being less than the high range of Finland, Germany, Italy, Switzerland and Spin. 


\section{University of Thi-Qar Journal Vol.12 No.1 Mar 2017 \\ Web Site: https://jutq.utq.edu.iq/index.php/main \\ Email: journal@jutq.utq.edu.iq}

The radon exhalation rate of water in this study was less than radon exhalation rate in term area and mass of water in India were $\left(245.21-690.24 \mathrm{mBq} \cdot \mathrm{m}^{-2} \cdot \mathrm{h}^{-1}\right)$ and $\left(8.95-25.08 \mathrm{mBq} \cdot \mathrm{kg}^{-1} \cdot \mathrm{h}^{-1}\right)$ respectively [Chauhan et al., 2001].

Table 5. Radium concentration in drinking water in some countries [UNSCEAR, 2000].

\begin{tabular}{|l|l|}
\hline The country & $C_{R a} B q \cdot \mathrm{kg}^{-1}$ \\
\hline United State & $0.0004-0.0018$ \\
\hline China & $0.0002-0.12$ \\
\hline Finland & $0.010-49$ \\
\hline France & $0.007-0.7$ \\
\hline Germany & $0.001-1.8$ \\
\hline Italy & $0.0002-1.2$ \\
\hline Poland & $0.0017-0.0045$ \\
\hline Romania & $0.0007-0.021$ \\
\hline Switzerland & $0-1.5$ \\
\hline Spin & $<0.02-4$ \\
\hline UK & $0-0.18$ \\
\hline
\end{tabular}

The diagram between radon exhalation rate in term of area and radium concentration, and also between radon exhalation rate in term of mass and radium concentration were linear one $\left(R^{2}=1\right)$, where $R^{2}$ is the squire of the correlation coefficient, these diagrams showed in figures 3 and 4 respectively. 


\section{University of Thi-Qar Journal Vol.12 No.1 Mar 2017 \\ Web Site: https://jutq.utq.edu.iq/index.php/main \\ Email: journal@jutq.utq.edu.iq}

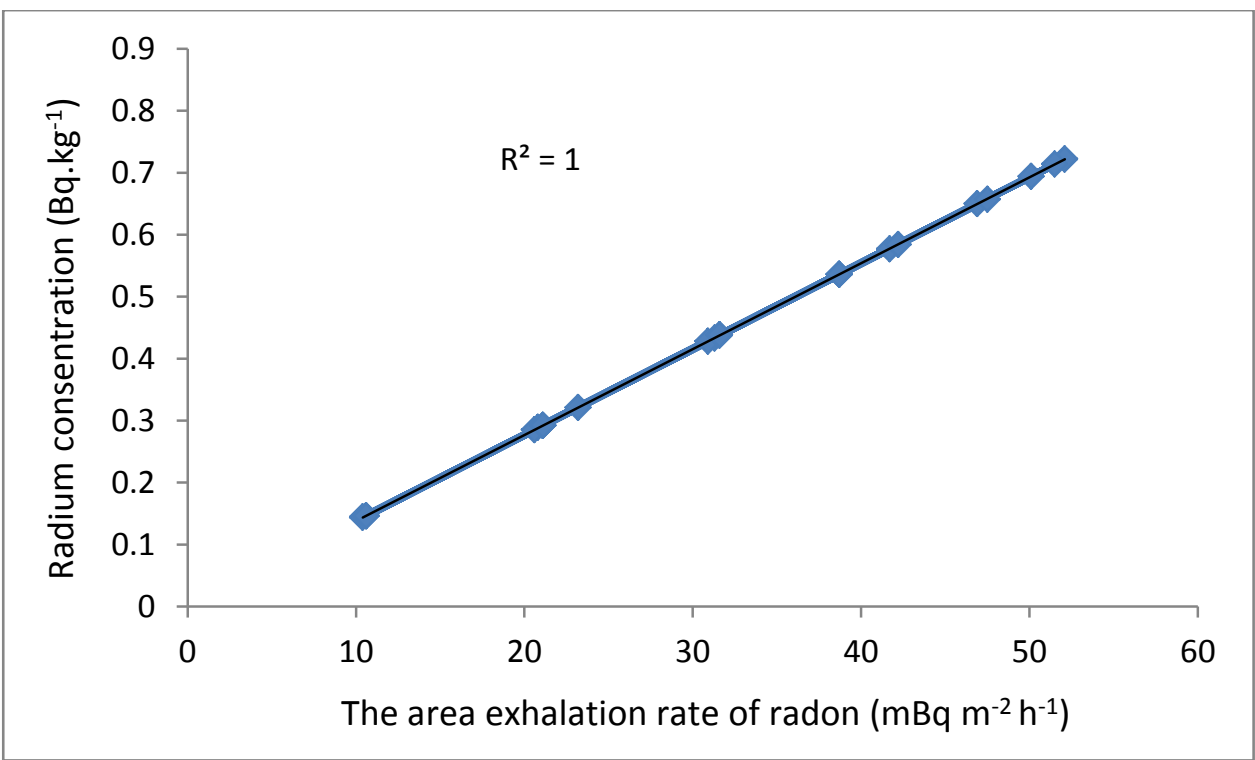

Figure 3. Show the relation between the area exhalation rate of radon and radium concentration.

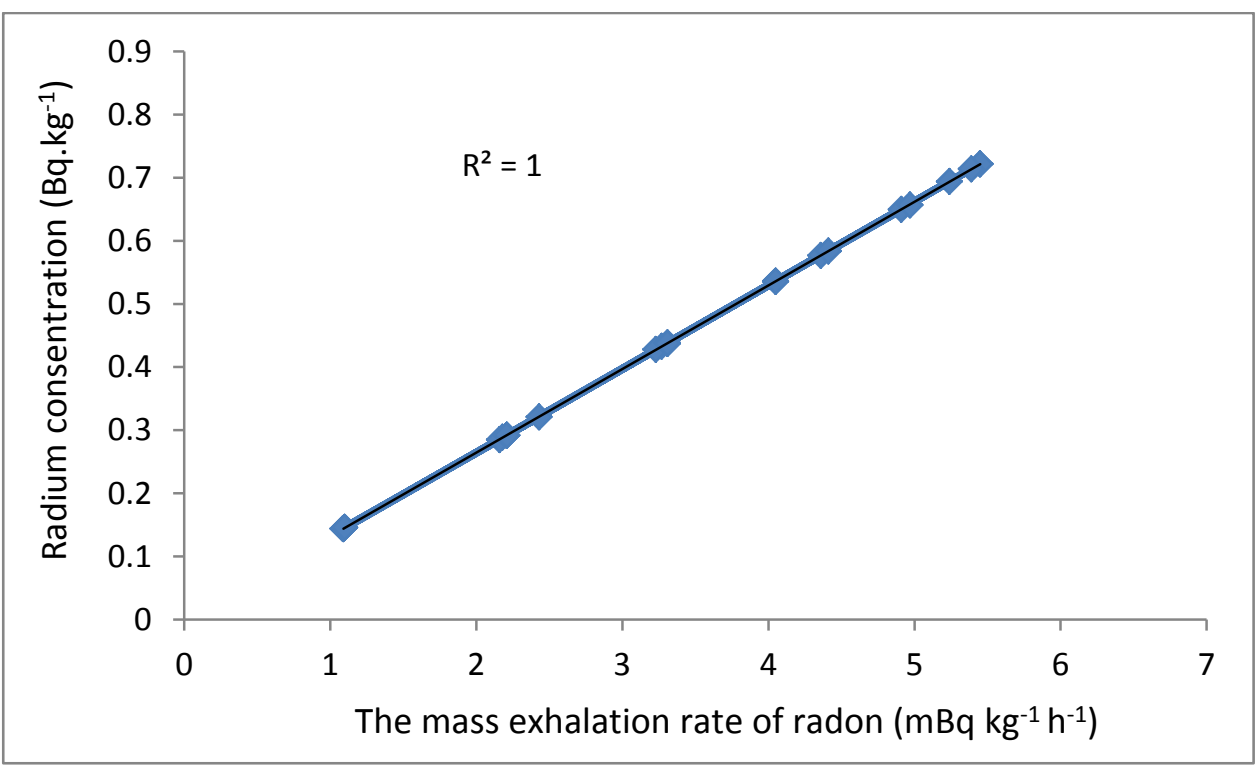

Figure 4. Show the relation between the mass exhalation rate of radon and radium concentration. 


\section{University of Thi-Qar Journal Vol.12 No.1 Mar 2017 \\ Web Site: https://jutq.utq.edu.iq/index.php/main \\ Email: journal@jutq.utq.edu.iq}

\section{Conclusion}

1- Radium concentration in water of Gharraf canal and its some branches was included the safe recommended according to WHO. But the most results were bigger than the maximum allowed value according to EPA.

2- The annual effective dose of radium in drinking water is exceeding recommended limits suggested by WHO in three samples in Al-Rufai region for three population groups. Generally, the annual effective dose of radium in drinking water for children was exceeding the recommended limit in many branches and in average in Al-Rufai region, Al-Nassiriah region and total. When used the Jordanian level that the results the annual effective dose of radium in drinking water were below.

3- The lifetime risk assessment was about $10^{-4}$.

4- Radium concentration in water of Gharraf canal was about middle when compared to the radium concentration in drinking water in other countries.

5- From figures 3 and 4 the linear relation between (the area exhalation rate of radon and radium concentration) and (the mass exhalation rate of radon and radium concentration). This led, from radium concentration can get a good estimate about radon exhalation rate or versa.

\section{Acknowledgement}

The author is grateful to (Prof. Dr. Isa Jasem Al-Khalifa), Department of Physics, College of Education for Pure Science, Basrah University for providing all necessary facilities for carrying out this work, and also thanks to (Fouad Nimr Ajeel), Department of Physics, College of Science, Thi Qar University and (Hussein Khashan Ghadhban), Statistics Directorate of Thi Qar who provided some information to complete this work. 
University of Thi-Qar Journal Vol.12 No.1 Mar 2017

Web Site: https://jutq.utq.edu.iq/index.php/main

Email: journal@jutq.utq.edu.iq 


\section{University of Thi-Qar Journal Vol.12 No.1 Mar 2017 \\ Web Site: https://jutq.utq.edu.iq/index.php/main \\ Email: journal@jutq.utq.edu.iq}

\section{References}

[1] Al-Khalifa I. J. M., Polymers track detector used for radon survey in Babel city (Al-Hillah-Iraq), J Basrah Researches (Sciences), 32, Part. 2, 26-30, 2006.

[2] Barooah D., Barman S. and Phukan S., Study of environmental radon exhalation, radium and effective dose in Dilli-Jeypore coalfield, India using LR-115 (II) nuclear track detectors, Indian Journal of Pure \& Applied Physics, 51, 690-695, 2013.

[3] Singh S., Sharma D. K., Dhar S., Kumar A. and Kumar A., Uranium, radium and radon measurements in the environs of Nurpur area, Himachal Himalayas, India, Environ Monit Assess, 128, 301-309, 2007.

[4] Mahur A. K., Khan M. S., Naqvi A. H., Prasad R. and Azam A., Measurement of effective radium content of sand samples collected from Chhatrapur beach, Orissa, India using track etch technique. Radiation Measurements, 43, 520-522, 2008.

[5] Kurnaz A. and Atıf Çetiner M., Exposure assessment of the radon in residential tap water in Kastamonu, International Journal of Radiation Research, 14, 3, 2016

[6] Voronov A. N., Radon-rich waters in Russia, Environmental geology, 46, 630-634, 2004.

[7] Tabar E. and Yakut H., Determination of 226Ra concentration in bottled mineral water and assessment of effective doses, a survey in Turkey, International Journal of Radiation Research, 12, (3), 193-201, 2014

[8] Jabir M. A., Geographical abilities for the farming of the vegetables in Thi - Qar governorate), Master Thesis, University of Basrah, 2008.

[9] Ahmed Z. W., Environmental analysis to geographical factors influential in the quantity and quality of fallen air in Dhi - Qar governorate, Master Thesis, University of Basrah, 2007.

[10] CSO, Central Statistical Organization, Ministry of planning, Republic of Iraq, 2014. 


\section{University of Thi-Qar Journal Vol.12 No.1 Mar 2017 \\ Web Site: https://jutq.utq.edu.iq/index.php/main \\ Email: journal@jutq.utq.edu.iq}

[11] EPA, Environmental Protection Agency, Radionuclides in Drinking Water,

https://cfpub.epa.gov/safewater/radionuclides/radionuclides.cfm?action= Rad_Reverse+Osmosis, 2015.

[12] Sonkawade R.G., Kant K., Muralithar S., Kumar R. and Ramola R.C., Natural radioactivity in common building construction and radiation shielding materials, Atmospheric Environment, 42, 2254-2259, 2008.

[13] Prasad Y., Prasad G., Gusain G.S., Choubey V.M. and Ramola R.C., Radon exhalation rate from soil samples of South Kumaun Lesser Himalayas, India, Radiation Measurements, 43, 369-374, 2008.

[14] Somogyi G., Paripas B. and Varga Zs., Measurement of radon, radon daughters and thoron concentrations by multi-detector devices, Nuclear Tracks and Radiation Measurements, 8, (1-4), 423-427, 1984.

[15] Misdaq M. A., Moustaaidine H., Satif C. and Charik R., A new method for evaluating the influence of building materials on radon emanation in Marrakechi dwellings, Appl. Radiat. Isot. 48, (1), 111-115, 1997.

[16] Klein D., Pautov V., Chambaudet A. and Barenboim G., Radon emanation measurement using French and Russian track detectors, Radiation Measurements 25, (1-4), 601- 602, 1995.

[17] Fahad M., Calibration of LR-115 for uranium estimation and radon measurements from phosphate and coal, Phys. Chem. News, 2, 63-65, 2001.

[18] ICRP, International Commission on Radiological Protection, Human respiratory tract model for radiological protection. Annals of the ICRP 24 (1-3). ICRP Publication 66. Pergamon Press, Oxford, 1994.

[19] UNSCEAR, Report of the United Nation Scientific Committee on the Effect of Atomic Radiation to the General Assembly, ANNEX B; Exposures from natural radiation sources, 2000.

[20] ICRP, International Commission on Radiological Protection, Agedependent doses to members of the public from intake of radionuclides: part 5. Compilation of ingestion and inhalation dose coefficients. ICRP 


\section{University of Thi-Qar Journal Vol.12 No.1 Mar 2017 \\ Web Site: https://jutq.utq.edu.iq/index.php/main \\ Email: journal@jutq.utq.edu.iq}

Publication 72. Annals of the ICRP 26 (1). Pergamon Press, Oxford, 1996.

[21] WHO, World health organization, Guidelines for third edition recommendations drinking-water quality, vol.1, Geneva, 2004.

[22] EPA, Environmental Protection Agency, Determination of radium removal efficiencies in water treatment process. Technical note. ORP/TAD-76-5, Illinois, EPA, Springfield, 1976.

[23] Al-Amir S. M., Al-Hamarneh I. F., Al-Abed T. and Awadallah M., Natural radioactivity in tap water and associated age-dependent dose and lifetime risk assessment in Amman, Jordan, Applied radiation and isotopes, 70, 692-698, 2012.

[24] ICRP, 1990 Recommendations of the international Commission on Radiological Protection, ICRP Publication 60. Pergamon Press, Oxford, 1991.

[25] Chauhan R.P., Kant K., Mahesh K. and Chakarvarti S.K., Radium concentration and radon exhalation measurements in the water around thermal power plants of north India, Indian J. Pure \& Appl. Phys., 39, 491-495, 2001. 